\title{
Funkcjonowanie nieletnich w ośrodku kuratorskim
}

\section{Functioning of juveniles in a probation officer's centre}

\section{STRESZCZeNIE}

Artykuł zwraca uwagę na funkcjonowanie nieletnich w ośrodku kuratorskim. Ustawodawca dość szeroko określił zakres działalności ośrodków. Wśród wielu realizowanych zadań personel podejmuje w nich pracę z nieletnimi, którzy zostali skierowani orzeczeniem sądu rodzinnego w związku z demoralizacją bądź popełnieniem czynu karalnego. Algorytm pracy w ośrodku kuratorskim określa działania podejmowane względem nieletnich, jednak $\mathrm{w}$ opracowaniach brakuje spojrzenia na sytuacje z perspektywy samych nieletnich. Artykuł ukazuje także swoiste techniki adaptacyjne podejmowane przez nieletnich w nowej dla nich sytuacji, jaką niewątpliwie jest skierowanie ich do ośrodka kuratorskiego, porównując je z tymi prezentowanymi przez uczestników w placówkach izolacyjnych.

Opracowanie uzupełniają: dostępne statystyki odnośnie do liczby nieletnich skierowanych do ośrodków kuratorskich (na tle statystyk dotyczących ogółu nieletnich, względem których orzeczono środki wychowawcze); opis zadań realizowanych w ośrodkach kuratorskich, krótką charakterystykę metodyki pracy oraz wnioski dla praktyki. Artykuł prezentuje zagadnienia z perspektywy zarówno teoretyka, jak i praktyka, co pozwala uchwycić szerszą perspektywę działalności ośrodków kuratorskich.

SŁOWA KLUCzowE: nieletni, ośrodek kuratorski, kurator sądowy. 


\section{SUMmaRY}

The article draws attention to the functioning of juveniles in a probation officer's centre.

The legislator has defined the scope of the centres' activities quite broadly. Among the tasks carried out, the staff undertake work with juveniles who have been referred by family court for demoralisation or criminal offences. The algorithm of work in the probation officer's centre defines the actions taken against minors, but the studies lack an idea of the situation from the perspective of the minors themselves. The article also reveals the specific adaptation techniques undertaken by juveniles in a new situation for them, which is undoubtedly directed to the probation officer's centre, comparing them with those presented by the participants in isolation facilities.

The study is complemented by available statistics on the number of minors sent to probation officer's centres (against the background of statistics on all minors for whom educational measures have been taken); a description of the tasks carried out in the probation officer's centres, a brief description of the working methodology and conclusions for the practice. The article presents issues from the perspective of both theorist and practice, which allows to capture a broader perspective of the activities of probation officer's centers.

KEYWORDS: juvenile, probation officer's centre, probation officer.

\section{Wprowadzenie}

W ostatnich latach (2017-2019) w statystykach Wymiaru Sprawiedliwości (2020, s. 170-173) liczba nieletnich, względem których orzeczono środki wychowawcze, zdaje się spadać. W roku 2019 w związku z demoralizacją do 15818 spraw (z 16335 w 2018 r.), natomiast do 11428 spraw (z 11952 w 2018 r.) w związku z czynami karalnymi. Obniża się także wiek nieletnich objętych postępowaniem. W $2018 \mathrm{r}$. w przypadku postępowań związanych $\mathrm{z}$ demoralizacją największy wzrost odnotowano kolejno $\mathrm{w}$ grupach wiekowych: do 12 lat (393 osób), 14-latków (259 osób), 13-latków (255 osób) i 15-latków (233 osób). Wśród 17-latków odnotowano wyraźny spadek (127 osób). Podobny trend, choć na mniejszą skalę, odnosił się do postępowań wynikających z popełnienia czynu karalnego. Wyraźny wzrost odnosił się do najmłodszej grupy objętej statystyką 13-latków (139 osób), największy spadek zaś dotyczył najstarszych 16-latków 
(100 osób). Środek wychowawczy w postaci skierowania do ośrodka kuratorskiego w 2018 r. orzeczono względem 501 nieletnich (355 - demoralizacja, 146 - czyn karalny). Liczba ta wydaje się niewystarczająca, jeśli uwzględnimy, że ośrodki kuratorskie zostały uznane za placówki, które świetnie funkcjonują (Gajos-Kaniewska, 2019) i najtańsze z form oddziaływania wychowawczego, osiągające wysokie efekty pracy resocjalizacyjnej z nieletnimi przy stosunkowo niskim miesięcznym koszcie utrzymania uczestnika (Bałandynowicz, 2015, s. 67-73). Nie bez znaczenia jest również fakt, że ośrodki umożliwiają bezpłatne wyrównywanie opóźnień szkolnych, co A. Bałandynowicz uznał za jeden z najistotniejszych celów sprzyjających prawidłowej socjalizacji (por. Korona, 2020).

\section{Zadania realizowane przez ośrodki kuratorskie}

Zgodnie z Wykazem ośrodków kuratorskich (2018) w Polsce funkcjonuje ich 97. Brakuje informacji odnośnie do aktualnych statystyk, co znacząco utrudnia oszacowanie obecnych trendów. Odnosząc te dane do liczby nieletnich, wobec których ten środek wychowawczy jest wykonywany - 1471 osób (2019 r.), pojedyncza placówka miałaby pod opieką średnio 15 nieletnich. Powinno to umożliwiać nie tylko indywidualizację oddziaływań, ale również pracę w grupach.

Pracę ośrodków reguluje rozporządzenie Ministra Sprawiedliwości z 5 października 2001 r. w sprawie ośrodków kuratorskich (Dz.U. nr 120, poz. 1294). Są one placówkami resocjalizacyjnymi o charakterze otwartym, działającymi w miejscu zamieszkania nieletniego. Głównym celem ich funkcjonowania ustawodawca uczynił zmianę „postaw uczestników w kierunku społecznie pożądanym, zapewniającym prawidłowy rozwój ich osobowości” ( $\$ 5.1$ ). Osiągnięcie tego celu ma mieć miejsce poprzez działalność profilaktyczną, opiekuńczo-wychowawczą oraz resocjalizacyjno-terapeutyczną, utożsamiane z jej funkcjami. Katalog ten wydaje się stanowić spójną propozycję, pozwalającą na dostosowanie prowadzonych oddziaływań do potrzeb uczestników. W dalszej części paragrafu wyznaczono 9 zadań szczegółowych, które powinny być realizowane w ramach działalności ośrodków: „zaspokajanie potrzeb osobowościowych, rozwiązywanie problemów psychicznych, uczenie 
samodzielnego radzenia sobie $\mathrm{z}$ trudnościami życiowymi, eliminowanie zaniedbań wychowawczych i edukacyjnych oraz wyrównywanie zaniedbań środowiskowych, wdrażanie do przestrzegania norm społecznych, rozwijanie zainteresowań, wyrabianie właściwych nawyków spędzania czasu wolnego, rozładowywanie napięć emocjonalnych, kształtowanie poczucia odpowiedzialności i opiekuńczości” (\$5.1 Rozporządzenia).

Analizując główne zadania, działalność resocjalizacyjna w warunkach ośrodka sprowadza się do organizowania nieletnim zajęć pod nadzorem i z udziałem kadry, z możliwością stwarzania im szansy do podejmowania coraz bardziej autonomicznych działań. Powinna ona także obejmować uczestnictwo (indywidualne i grupowe) w różnych formach aktywności - kulturalnej, rozrywkowej, sportowej lub rekreacyjnej. Kryterium wyboru stanowić powinny zainteresowania uczestników, chociaż równie ważne jest umożliwienie im uczestnictwa w działalności, z którą z uwagi na wadliwy przebieg socjalizacji czy wychowania mogli się nie zetknąć. Resocjalizacja powinna umożliwić jednostce proces destygmatyzacji, poprzez włączenie społeczeństwa w zakres prowadzonych oddziaływań, dążąc do resocjalizacji inkluzyjnej (Kozłowski, Stasiak, 2018, s. 69-70). Funkcja wychowawcza jest realizowana poprzez systematycznie prowadzony przez kadrę proces wychowania, zmierzający do zmiany postaw uczestników, ale także wsparcie zapewniane jego rodzinie poprzez warsztaty dla rodziców czy opiekunów prawnych. Te ostatnie w praktyce zdają się mieć charakter doraźny, zamiast skoordynowanych działań. Działania opiekuńcze to głównie sprawowanie opieki nad nieletnimi w trakcie ich pobytu na zajęciach i zapewnienie im bezpieczeństwa, co uzasadnia standard maksymalnie 20 nieletnich skierowanych do ośrodka i obecność minimum 2 pracowników (Kozłowski, Stasiak, 2018, s. 71). W ramach tych działań wliczone jest także przygotowanie posiłku, pozostawiając jego organizację do decyzji kierownika (uwzględniając dość skromny budżet) - samodzielnie przez nieletnich, wspólne gotowanie czy korzystanie z zewnętrznych usług. Profilaktyka, jak wskazują P. Kozłowski i K. Stasiak (2018, s. 71-72), obejmuje dwa poziomy: selektywny, związany z czasową izolacją nieletnich, opóźnieniem inicjacji zachowań ryzykownych oraz przepracowaniem posiadanych doświadczeń, aby wyposażyć ich w wie- 
dzę i umiejętności pozwalające unikać podobnych aktywności oraz wskazujący, odnoszący się do poważniejszych - dysfunkcyjnych zachowań, aby ograniczyć ich czas trwania. Terapeutyczne zadania wydają się najbardziej kontrowersyjne, gdyż bywają utożsamiane $\mathrm{z}$ resocjalizacją (por. Czapów, 1980; Sawicka, 2007; Szczepaniak, 2009) bądź kwestionowane (Konopczyński, 2014). W warunkach ośrodka rozporządzenie (\$7.2 pkt 3) nie precyzuje jej form. Charakter podejmowanych działań uzasadnia, aby były one podejmowane przez wykwalifikowany personel - posiadający uprawnienia do prowadzenia terapii. Poprzedzać powinna je diagnoza, która w kurateli sądowej także stanowi obszar wymagający doprecyzowania (por. Wojnarska, Korona, 2020).

W kwestii zadań szczegółowych, po części w związku z dylematami diagnostycznymi, najwięcej kontrowersji wśród praktyków budzi rozwiązywanie problemów psychicznych nieletnich. Nie wszystkie ośrodki współpracują z psychologami lub w zasobach kadrowych mają osoby merytorycznie przygotowane do pracy terapeutycznej. Większość zadań szczegółowych realizowana jest z wykorzystaniem zróżnicowanej oferty zajęć - zarówno indywidualnych, jak i grupowych. Następstwem uczęszczania do ośrodków ma być szereg korzyści: rozwijanie umiejętności samoobsługowych, np. przygotowywanie posiłku czy dbanie o czystość otoczenia, rozwijanie poziomu umiejętności społecznych, zaproponowanie konstruktywnych sposobów na spędzanie czasu wolnego czy kontrolę emocji, wypracowywanie nawyku systematycznej pracy (Kwadrans, 2012). Nieletni w ośrodku mają do wykonania jasno sprecyzowane obowiązki i szansę zmierzyć się z zadaniami, których nie wymagano od nich w domu, oraz poznać aktywności, których dotychczas nie podejmowali. Niejednokrotnie pozwala im to odnaleźć nowe pasje czy aktywności, w których mają szansę realizować się z sukcesem. Na każdym etapie mogą liczyć na towarzystwo i wsparcie innych uczestników oraz kadry. Nadal aktualnym zadaniem, które często pochłania dużo czasu, jest udzielanie podopiecznym pomocy w nauce i wyrównywanie braków edukacyjnych. Ośrodek jest jednym z niewielu miejsc, w których nieletni mogą otrzymać bezpłatną pomoc w nauce. Część ośrodków nawiązuje w tym zakresie współpracę ze szkołami podopiecznych. Tym samym nieletni mogą uczyć się z nauczycielem, który ma szansę 
ujrzeć ich w innym świetle i docenić podejmowane przez nich wysiłki (co nie zawsze możliwe jest w ramach aktywności w klasie). Jednocześnie stanowi to obszar pracy wymagający sporego wyczucia ze strony kadry. Często nieletni demonstrują negatywny stosunek emocjonalny do nauczycieli, szczególnie z przedmiotów, z których czują się słabsi, co $\mathrm{w}$ ich ocenie może uniemożliwiać wspólną naukę z nauczycielem. Niedocenianą sferą jest wysiłek podejmowany przez kadrę w zakresie pomocy w nauce. Poza wymiarem korepetycji (różnym w poszczególnych ośrodkach) często kuratorzy czy wolontariusze starają się pomagać na bieżąco z zadaniami, niejednokrotnie niezależnie od ich tematyki czy poziomu kształcenia.

Realizację zadań utrudniają także specyficzne problemy w postaci: braku zainteresowania ze strony rodziców lub nieadekwatne oczekiwania $z$ ich strony, znikome zainteresowanie współpracą ze strony organizacji i jednostek samorządowych czy nadmierne obciążenie dla kadry.

\section{Algorytm pracy w ośrodku kuratorskim a sytuacje nowe}

Nieletni kierowani są do ośrodków kuratorskich na podstawie orzeczenia sądu ( $\$ 6.1$ Rozporządzenia). Procedura postępowania kierownika i wychowawców wykonujących środek wychowawczy w postaci skierowania do ośrodka kuratorskiego (Kwadrans, 2018, s. 858) rozpoczyna się od otrzymania odpisu orzeczenia i zapoznania się z aktami sprawy. Następnie zakładana jest teczka nieletniego, jest on wpisywany do dziennika i wraz z rodzicami wezwany do stawienia się w ośrodku kuratorskim (w wyznaczonym terminie). Dalsze działania uzależnione są od ich stawiennictwa. Jeśli się pojawią, zostaje nawiązany kontakt. W trakcie rozmowy kierowanej nowy uczestnik pouczany jest o prawach i obowiązkach, otrzymuje informacje na temat funkcjonowania ośrodka i odpowiedzi na nurtujące go pytania. Kadra natomiast uzyskuje informacje, pozwalające na zdiagnozowanie sytuacji nieletniego, sformułowanie diagnozy oraz planu działań korekcyjno-wychowawczych. Mogą one zostać uzupełnione o informacje $\mathrm{z}$ innych instytucji, które współpracują z rodziną. Nieletni stopniowo jest włączany do grupy, poddawany indywidualnym oddziaływaniom oraz 
uczestniczy w organizowanych w placówce zajęciach. W czasie realizacji planu pracy systematycznie podopieczny jest obserwowany, analizowane są jego postępy. Ponadto we wskazanych odstępach czasu - np. co 3 miesiące, kadra przygotowuje pisemne sprawozdanie o uczestniku, opisujące jego funkcjonowanie w różnych obszarach (w tym spostrzeżenia odnośnie do skuteczności podejmowanych działań i kierunków dalszej pracy). Jeśli nieletni wraz z rodzicem (opiekunem prawnym) nie stawi się, w miejscu zamieszkania, przeprowadzany jest wywiad środowiskowy, który ma dać odpowiedź odnośnie do sytuacji podopiecznego. Dalej procedura wraca na właściwe tory, tj. sformułowanie diagnozy i planu działań, stopniowa integracja i korzystanie z oferty ośrodka. Pisemne sprawozdania oraz ewentualne wnioski kierownika ośrodka stają się podstawą dla sędziego, który podejmuje decyzję odnośnie do dalszego przebiegu postępowania - jego umorzenia, kontynuacji bądź zmiany orzeczonego środka wychowawczego. Jak stanowi treść Ustawy o postępowaniu w sprawach nieletnich (art. 73, Dz.U. 2018, poz. 969), zobowiązanie ustaje z mocy prawa po ukończeniu 18. roku życia przez nieletniego.

Poza stroną formalną trudno jest zignorować stronę emocjonalną funkcjonowania nieletniego. Podopieczni ośrodków kuratorskich niejednokrotnie w badaniach uzyskują słabsze wyniki od rówieśników (Kwadrans, 2018, s. 847) w zakresie uwarunkowań psychofizycznych czy relacji interpersonalnych, jednak niewiele jest badań w tym zakresie. Dodatkowymi problemami są: opóźnienia szkolne i zaniedbania dydaktyczne, mniej korzystny sposób funkcjonowania psychofizycznego, a nawet problemy psychiczne, negatywizm szkolny, niska motywacja do nauki, zubożenie potrzeb poznawczych czy zainteresowań. Charakterystyka zasobów osobistych młodzieży nieprzystosowanej społecznie w zakresie poczucia koherencji, prężności i sprężystości ujawniła u nieletnich raczej przeciętny poziom badanych zmiennych (Konaszewski, Kwadrans, 2018). Skierowanie do ośrodka kuratorskiego stanowi dla nieletnich rodzaj sytuacji nowej, a być może także trudnej. Dodatkowo informacja o skierowaniu do ośrodka konfrontowana jest $\mathrm{z}$ opiniami kolegów, doniesieniami medialnymi i wyobrażeniami na ten temat.

Ośrodki kuratorskie nie wyczerpują znamion instytucji totalnej w ujęciu E. Goffmana (2011), jednak wymienione przez niego taktyki 
adaptacyjne zdają się nie odbiegać zbytnio od tego, co możemy zaobserwować wśród nieletnich. Zwrócił on uwagę na 5 zachowań, które wynikają z kalkulacji i ekspozycji siebie w relacjach z innymi osadzonymi i personelem: wycofanie, bunt, zadomowienie (kolonizacja), konwersja czy zimna kalkulacja (kombinacja). Ich charakterystyka zdaje się odpowiadać zachowaniom wybieranym także przez nieletnich. Część uczestników początkowo decyduje się nie angażować w sytuację, preferując obserwowanie wydarzeń, zamiast aktywne w nich uczestnictwo. Inną często spotykaną reakcją jest otwarte kwestionowanie zasad panujących $\mathrm{w}$ ośrodku i samego pobytu w nim, poprzez prowokowanie personelu i innych uczestników, czasem połączone z odmową współpracy. Kolejne wybory w większym stopniu odnoszą się do prób odnalezienia się w nowej rzeczywistości poprzez poszukiwanie obszarów, w których nieletni mogliby się realizować i względnie spokojnie egzystować. W bardziej zaawansowanym etapie podopieczni przejmują poglądy personelu i ich spojrzenie na funkcjonowanie instytucji, konsekwentnie punktując przewinienia innych uczestników, niejednokrotnie domagając się ich ukarania. Ostatnim wyodrębnionym zachowaniem jest zimna kalkulacja, związana z bieżącym szacowaniem zysków i strat, związanych z podjęciem określonego zachowania. W dynamice funkcjonowania nieletnich w ośrodku niektórzy z nich przez dłuższy czas wybierają jedną taktykę, jednak przeważająca większość manewruje między nimi, stosownie do aktualnej sytuacji. Brakuje opracowań, które koncentrowałyby się na tej kwestii, zwracając uwagę właśnie na dynamikę funkcjonowania nieletnich, chociaż niektóre $\mathrm{z}$ zachowań znajdują bezpośrednie przełożenie $\mathrm{w}$ dynamice pracy grupowej.

Idąc o krok dalej, lęk towarzyszący pierwszemu pojawieniu się w ośrodku przyrównać można do technik adaptacyjnych, związanych z pokonywaniem miejsca, opisanymi przez R. Szczepanik (2015) w odniesieniu do zakładów karnych i co za tym idzie - chęcią wykreowania odpowiedniego wizerunku w placówce czy zajęcia określonej pozycji w grupie. Wymieniono 2 główne typy „nowo przybyłych”, opisujące specyficzny sposób regulowania relacji z otoczeniem czy zajmowania pozycji wśród innych uczestników: świadomy gracz (ma orientację w zakresie zachodzących w placówce procesów, przejawia inicjatywę 
i aktywność, aby osiągnąć określony cel, wyciąga wnioski z nieskutecznych działań) oraz typ obronny (podejmuje działania defensywne, często intuicyjnie, stara się balansować wizerunkowo pomiędzy agresorem a ofiarą). Autorka wyróżniła także 9 taktyk unikania opresji i wytwarzania środowiska opresji, służących zapanowaniu nad lękiem oraz lękiem przed lękiem (negatywnymi emocjami) i pokonywaniu miejsca (budowaniu pozycji w placówce). Są to: szukanie sojuszników, otwarta konfrontacja (związana $\mathrm{z}$ budowaniem wizerunku osoby wolnej od lęku poprzez tworzenie warunków do wykazania się pożądanymi cechami - siłą, odwagą czy nieugiętością, nawet kosztem konfliktu z personelem), wyczulenie (łączy w sobie redukowanie frustracji przez wyładowanie negatywnych emocji oraz podtrzymywanie wizerunku osoby nieobliczalnej i niebezpiecznej), autoagresja, postawienie się (związany z nawykiem szybkiego reagowania na zaczepki i nieulegania presji), odnalezienie chłopca do bicia (budowanie pozycji poprzez opresyjne zachowania i szukanie słabszej osoby, celem narzucania jej statusu „kozła ofiarnego” w celu zminimalizowania ryzyka bycia ofiarą), testowanie pozycji (związane z weryfikacją zdobytej pozycji i kreowaniem podziałów w grupie), sterowanie uwagą (charakteryzuje zarządzanie sytuacjami, pozostając w centrum zainteresowania) oraz grypsowanie (zapewnienie sobie przynależności do grupy o ukonstytuowanej pozycji). Koncepcja ta nie jest do końca spójna, gdyż poszczególne taktyki mogą przenikać się czy nawet łączyć, jednak oddają pewną wielość możliwości poradzenia sobie przez jednostkę w sytuacji nowej, jaką jest zetknięcie z placówką. Realia placówki wolnościowej nie przystają do tych w placówce izolacyjnej, jednak sposób zachowania podopiecznych w pewnych obszarach zdaje się nakładać na nie.

Specyfika funkcjonowania ośrodków kuratorskich pozwala na wyodrębnienie 4 kategorii sytuacji nowych, być może także trudnych, z którymi będą wiązały się określone problemy. Pojawienie się w placówce to przede wszystkim konfrontowanie oczekiwań własnych nieletniego $\mathrm{z}$ opinią obiegową na temat funkcjonowania ośrodka. Uczestnictwo w zajęciach wymaga: konfrontacji posiadanego poziomu wiedzy czy umiejętności z wyobrażeniami nieletnich na ten temat (może pojawić się obawa przed oceną i ujawnieniem skali zaległości), ujawnienia in- 
formacji na temat rodziny i panujących w niej relacji oraz dokonywania porównań z rodzinami innych uczestników (sytuacja ta może wzbudzać lęk, uczucie wstydu, a czasem złość). W relacjach rówieśniczych sytuacją nową jest konieczność zajęcia określonego miejsca w grupie, zawalczenia o pozycję czy nawiązywania nowych kontaktów (trudnymi mogą okazać się współpraca z uczestnikami w różnym wieku czy odmiennej płci, chęć zaimponowania im czy zdobycia akceptacji, mogą wystąpić także zachowania typowe dla placówek izolacyjnych, związane z „pokonywaniem miejsca").

Ostatnia grupa to postrzeganie społeczne, w którym sytuacja nowa będzie obejmowała przede wszystkim obawę o dotychczasowe relacje (trudna może okazać się konfrontacja z wizerunkiem uczestnika czy reakcją otoczenia na wieść o skierowaniu nieletniego do ośrodka, która może zburzyć dotychczasowe wyniki np. funkcjonowania szkolnego). Jak wskazuje praktyka, w wielu przypadkach, zarówno nieletni, jak i ich rodzice/opiekunowie prawni obawiają się reakcji szkoły na informację o tym, że jeden z uczniów jest uczestnikiem postępowania sądowego. W nielicznych przypadkach zdarzało się, że informacja taka była brana pod uwage przy ocenie zachowania ucznia czy szacowaniu jego winy w niewłaściwych zachowaniach na terenie szkoły.

\section{Metodyka pracy w ośrodku kuratorskim}

Ustawodawca przewiduje 3 kategorie metod pracy z uczestnikami (\$ 7.1. Rozporządzenia): grupową, z indywidualnym przypadkiem oraz środowiskową. Zajęcia mają w szczególności polegać na ( $\$ 7.2$ Rozporządzenia): organizowaniu czasu wolnego, nawiązywaniu współpracy ze środowiskiem, prowadzeniu terapii, udzielaniu pomocy w usuwaniu zaniedbań wychowawczych i edukacyjnych.

W ramach współpracy ze środowiskiem, organizowane są głównie spotkania $\mathrm{z}$ rodzicami/opiekunami prawnymi, a także przedstawicielami różnych organizacji. Kadra ośrodków w wielu miastach stała się elementem lokalnych systemów wsparcia, resocjalizacji czy pomocy (Kwadrans, 2012), uczestnicząc w rozwiazywaniu obecnych w środowisku problemów społecznych. 
Metody pracy z indywidualnym przypadkiem odnoszą się do znanej na gruncie pedagogiki resocjalizacyjnej procedury antropotechniki interakcji dwuosobowej opisanej przez Cz. Czapówa (1980), koncentrującej się przede wszystkim na relacji między wychowankiem a wychowawcą. W ośrodkach kuratorskich do metod pracy indywidualnej zaliczane są m.in. (Kozłowski, Stasiak, 2018): kreowanie planów i celów życiowych, ABC trudnej sytuacji, casework czy mentalizacja zachowań. W wielu placówkach kadra pracuje, także wykorzystując dialog motywujący.

Wśród metod pracy grupowej w ośrodkach wymienia się (Kozłowski, Stasiak, 2018): kształtowanie dyscypliny, ekonomię punktową, metody kognitywno-behawioralne (praca ze zniekształceniami poznawczy$\mathrm{mi}$ ), trening zastępowania agresji (TZA), metody twórczej resocjalizacji, socjoterapię, mediacje, edukację prawną, projekty resocjalizacyjne, spotkania świąteczne i okolicznościowe (organizowanie nowych doświadczeń), cykliczne wydarzenia i przedsięwzięcia (o różnym zasięgu, często zawierające $\mathrm{w}$ sobie element współpracy czy rywalizacji między poszczególnymi ośrodkami).

Metodyka pracy ośrodków kuratorskich obejmuje także wiele autorskich programów kadry - m.in. z zakresu profilaktyki, socjoterapii, arteterapii czy sportterapii. Uwzględniając możliwe do osiągnięcia korzyści, jak nabycie/rozwinięcie umiejętności społecznych i kompetencji oraz ich potencjał kreacyjny, wraz z kreowaniem nowych potencjałów tożsamościowych, wpisuje się ona w założenia koncepcji twórczej resocjalizacji M. Konopczyńskiego (por. Kwadrans, 2018). Jej dużym atutem jest korzystanie z zasobów samych podopiecznych do budowania nowej tożsamości (innego sposobu myślenia o sobie i posiadanych priorytetach życiowych) i pozostawianie im decyzji odnośnie do uczestnictwa w oddziaływaniach.

Wymienione wyżej metody w różnych połączeniach wykorzystywane są w dominujących aktywnościach w ośrodku: organizowaniu czasu wolnego nieletnim, nadrabianiu zaległości edukacyjnych, autorskich warsztatach i zajęciach.

Z badań Ł. Kwadransa (2012, s. 857) wynikało, że w przeważającej większości ośrodków w zajęciach uczestniczyła grupa 5-10 uczestników. 
Zajęcia organizowane są głównie w siedzibie ośrodka kuratorskiego (pomieszczenia należące bądź wynajmowane przez sąd rejonowy), chociaż ustawodawca przewidział możliwość realizacji ich poza siedzibą (np. zajęcia sportowe czy wycieczki/wyjazdy wakacyjne) ( $\$ 7.3$ i 4 Rozporządzenia). Wymiar czasu pracy ośrodków został określony na czas nie krótszy niż 20 godzin zegarowych tygodniowo $(\$ 9.1)$, co w różnych ośrodkach obejmuje 4-5 godzin dziennie (uzależnione od tego, czy ośrodek pracuje 4 czy 5 dni w tygodniu). Kadrę tworzą kierownik, rodzinni kuratorzy zawodowi i społeczni oraz osoby posiadające specjalistyczne uprawnienia (\$ 8.1-3).

\section{Zakończenie i wnioski}

Ośrodki kuratorskie pozwalają na prowadzenie zaprogramowanych oddziaływań przez wykwalifikowaną kadrę, umożliwiając pozostawienie nieletniego w środowisku rodzinnym. Godziny pracy ośrodków pozwalają zagospodarować czas po skończeniu zajęć lekcyjnych, odsuwając nieletnich od środowiska osób zdemoralizowanych, bez konieczności umieszczania ich w placówkach izolacyjnych. Argumenty te są szczególnie ważne, jeśli uwzględnimy możliwość przyszłej „kariery przestępczej" nieletnich, której zapobiec można i należy w warunkach wolnościowych. Sposób funkcjonowania odmienny od placówek izolacyjnych sprawia, że nieletni na ogół chętnie uczestniczą w zajęciach. Dodatkowymi atutami jest wynikająca $z$ badań Krajowej Rady Kuratorów (Kwadrans, 2018, s. 868-869) wysoka skuteczność oddziaływań (potwierdzona licznymi wnioskami o uchylenie ośrodka, lepszymi wynikami szkolnymi nieletnich i faktem kontynuowania przez nich nauki i niewielkim odsetkiem tych, którzy mają postępowania w związku z demoralizacją czy popełnieniem czynu karalnego) przy niskich kosztach miesięcznych wydawanych na jednego nieletniego (46-924 zł). Mimo wielu zalet i możliwości, jakie stwarza skierowanie nieletniego do ośrodka kuratorskiego, nadal można zaproponować kilka rozwiązań, które mogłyby przyczynić się do jeszcze lepszego funkcjonowania tych placówek i co za tym idzie - większej skuteczności prowadzonych oddziaływań. 
Wnioski dla praktyki - postulowane zmiany:

$\triangleright$ Zatrzymanie trendu zamykania ośrodków i otwieranie nowych, aby sądy rodzinne w każdej miejscowości miały możliwość orzekania tego środka wychowawczego i tym samym równość w dostępie do prawa.

$\triangleright$ Zwiększenie środków na funkcjonowanie ośrodków (por. Dzierzyńska-Breś, Matkowski, 2020, s. 254-255), aby umożliwić większe zróżnicowanie oferty resocjalizacyjnej, uczestnictwo nieletnich w różnych aktywnościach, a także nowoczesne pomoce naukowe - np. aktualizacja sprzętu i oprogramowania stosownie do potrzeb uczestników.

$\triangleright$ Zwiększenie wymiaru godzin funkcjonowania ośrodków, aby w ramach realizowania funkcji wychowawczej w regularnej ofercie znalazły się warsztaty i spotkania z rodzicami/ opiekunami prawnymi.

$\triangleright$ Rozbudowanie sieci współpracy z rodzicami/ opiekunami prawnymi, aby zweryfikować ich nieadekwatne przekonania i zmotywować ich do większej aktywności.

$\triangleright$ Podwyższenie wynagrodzenia kadry. Szczególnie w przypadku osób zatrudnianych na umowy zlecenia stawka za godzinę specjalistycznych zajęć z młodzieżą czy opiekę nad nimi jest ta sama od wielu lat, a nawet niższa, co odbiera pracy w ośrodkach prestiż, a także utrudnia zatrudnienie specjalistów.

$\triangleright$ Ośrodki umożliwiają nadrobienie zaległości edukacyjnych z wielu przedmiotów szkolnych na poziomie szkoły podstawowej, średniej i zawodowej, dlatego zasadne byłoby zwiększenie wymiaru korepetycji i stawek wynagrodzenia za nie (aby były konkurencyjne $\mathrm{z}$ komercyjnymi) oraz umożliwienie uzyskania pomocy $\mathrm{z}$ przedmiotów zawodowych.

$\triangleright$ Zapewnienie szkoleń dla kadry, aby w większym stopniu stawiała na relacje z podopiecznymi (por. Matkowski, 2020), nie tylko na programy dla zwiększenia efektywności oddziaływań i poprawy frekwencji nieletnich.

$\triangleright$ Stworzenie zarysu metodyki pracy w ośrodkach kuratorskich, który mógłby zebrać i ujednolicić praktyki podejmowane w różnych ośrodkach. 
$\triangleright$ Rozwinięcie oferty zajęć socjoterapeutycznych - zwrócenie większej uwagi na zachowanie uczestników w początkowym etapie ich pobytu w ośrodku i położenie większego nacisku na integrację grupy.

$\triangleright$ Zacieśnienie współpracy ze środowiskiem naukowym w zakresie diagnozy uczestników, zwiększania oferty oddziaływań oraz ewaluacji prowadzonych działań.

$\triangleright$ Rozbudowanie możliwości włączenia studentów w działalność ośrodków kuratorskich - zajęcia metodyczne, praktyki studenckie czy wolontariat.

$\triangleright$ Dążenie do zapewnienia współpracy międzyresortowej, z Ministerstwem Edukacji i Nauki, Ministerstwem Rodziny i Polityki Społecznej oraz Ochotniczymi Hufcami Pracy, aby utrzymać równowagę systemu między placówkami wolnościowymi a izolacyjnymi, bez konieczności rozbudowywania tych ostatnich.

Od lat postulowane jest, aby oddziaływania prowadzone w ośrodkach kuratorskich miały charakter konwergencyjny i wynikały z celowego współdziałania wszystkich podmiotów wychowawczych. Ideałem byłoby stworzenie wewnątrz ośrodka swoistego mikrosystemu wychowawczego, w którym kuratorzy, personel i nieletni prezentować będą podobne przekonania wychowawcze, podobny system wartości i nastawienia. Tym samym, uwzględniając niezadowalającą skuteczność resocjalizacji nieletnich w placówkach izolacyjnych, należałoby zwrócić większą uwagę na funkcjonowanie ośrodków kuratorskich, które poza wskazanymi wcześniej zaletami wpisują się także w aktualne trendy w resocjalizacji.

\section{Bibliografia:}

Bałandynowicz A. (2015). Probacyjna sprawiedliwość karząca. Warszawa: Wydawnictwo Wolters Kluwer Polska

Czapów Cz. (1980). Wychowanie resocjalizujące. Elementy metodyki i diagnostyki. Warszawa: Wydawnictwo PWN

Dzierzyńska-Breś S., Matkowski S. (2020). The concept of working with juveniles in local community: activities and interactions based on evidence-based practice in attendance centres. Polska Myśl Pedagogiczna 6 (2020), s. $251-266$ 
Gajos-Kaniewska D. (2017). Ośrodki kuratorskie dobre dla dzieci i niedrogie - RPD pisze do ministra Ziobry, https://www.rp.pl/Edukacjai-wychowanie/311089946-Osrodki-kuratorskie-dobre-dla-dzieci-iniedrogie---RPD-pisze-do-ministra-Ziobry.html (dostęp: 31.05.2021)

Goffman E. (2011). Instytucje totalne. O pacjentach szpitali psychiatrycznych i mieszkańcach innych instytucji totalnych. Gdańsk: Gdańskie Wydawnictwo Psychologiczne

Konaszewski K., Kwadrans Ł. (2018). Zasoby osobiste młodzieży nieprzystosowanej społecznie. Uwarunkowania środowiskowe. Kraków: Oficyna Wydawnicza „Impuls”

Konopczyński M., (2014). Pedagogika resocjalizacyjna. W stronę działań kreujacych. Kraków: Oficyna Wydawnicza Impuls

Korona K. (2020). Oddziaływania edukacyjne w ośrodkach kuratorskich na przykładzie Sądu Rejonowego w Lublinie. W: D. Łukomiak, K. Łukomiak (red.), Nauki społeczne i humanistyczne. Varia. Łódź: Wydawnictwo Naukowe ArchaeGraph, s. 367-378

Kozłowski P., Stasiak K. (2018). Ośrodek kuratorski. Ujęcie prawne, organizacyjne i metodyczne. Warszawa: Biuro Rzecznika Praw Dziecka

Kwadrans Ł. (2012). Diagnoza aktualnej sytuacji i propozycje rozwoju ośrodków kuratorskich, „Probacja” 2012/3, s. 113-124

Kwadrans Ł. (2018). Ośrodek kuratorski - środek wychowawczy wykonywany przez kuratorów sądowych. W: K. Stasiak (red.). Zarys metodyki pracy kuratora sadowego. Warszawa: Wydawnictwo Wolters Kluwer

Matkowski S. (2020). Opiekun czy kontroler? O dylematach roli zawodowej kuratora sąowego, a efektywności jego oddziaływań. Badania i Rozwój Młodych Naukowców w Polsce. Nauki humanistyczne i społeczne. Społeczeństwo i edukacja. Poznań: Wydawnictwo Młodzi Naukowcy, s. 86-91

Rozporządzenie Ministra Sprawiedliwości z 5 października 2001 r. w sprawie ośrodków kuratorskich (Dz.U. 2001 Nr 120, poz. 1294)

Sawicka K. (2007). Terapia w resocjalizacji. W: B. Urban. J.M. Stanik (red.). Resocjalizacja. Teoria i praktyka pedagogiczna, t. II. Warszawa: Pedagogium WSPR, Wydawnictwo Naukowe PWN

Statystyka Wymiaru Sprawiedliwości (2020). Rocznik Statystyczny Rzeczypospolitej Polskiej. Warszawa: Główny Urząd Statystyczny, https://www.stat.gov. pl (dostęp: 02.06.2021)

Szczepaniak P. (2009). Znaczenie pojęcia terapii w pedagogice specjalnej. W: A. Rejzner, P. Szczepaniak (red.). Terapia w resocjalizacji. Część I. Ujęcie teoretyczne Warszawa: Wydawnictwo Akademickie ŻAK 
Szczepanik R. (2015). Stawanie się recydywistą. Kariery instytucjonalne osób powracajacych do przestępczości. Łódź: Wydawnictwo Uniwersytetu Łódzkiego

Ustawa z 26 października 1982 r. o postępowaniu w sprawach nieletnich (Dz.U. 2018, poz. 969)

Wojnarska A., Korona K. (2020). Zadania diagnostyczne kuratora sądowego - teoria i praktyka, Resocjalizacja Polska 20, s. 59-79Wykaz ośrodków kuratorskich (2018), https://www.arch-bip.ms.gov.pl/pl/dzialalnosc/osrodki-kuratorskie/ (dostęp z 04.06.2021) 